folk/ed. Derg, 2022; 28(1)-109. sayı

DOI: $10.22559 /$ folklor.1990

\title{
Doğu Türkistan'daki Sosyal Hayatın Edebiyata Yansıması: Bıyık Macerası ${ }^{1}$
}

\section{The Reflection of Social Life in East Turkestan to Literature: Moustache Adventure}

Reyila Kaşgarlı*

Öz

Çağdaş Uygur edebiyatında hikâye, 20. yüzyılın başlarında gelişmeye başlar. Realizm akımı 1949 yılından sonra yerini, sosyalist realizme bırakır. 1956 yılındaki "Fikir Özgürlüğü" sloganı ile topluma yararı olmayan mevki sahiplerinin eleştirildiği hiciv hikâyeleriyle canlanan Uygur hikâyeciliği, 1958 yılındaki "Yerli Milliyetçiliğe Karşı Mücadele” sloganıyla başlatılan aydınlara yönelik darbeden dolayı siyasi sınırlara hapsedilir. 1966-1976 yıllarında gerçekleşen Kültür Devriminde kayda değer bir eser yayımlanamaz. 1980'li yıllarda Çin'in kalkınma politikası nedeniyle baskı, bir nebze de olsa gevşer. Bu durum Uygur edebiyatına tarihî şahsiyetleri ve millî değerleri konu alan hikâyeleri kazandırır.

1990’lı yıllardan itibaren Memtimin Hoşur; Deli, Bıyık Macerası, Kenarlı Bardak,

Geliş tarihi (Received): 28-07-2021 - Kabul tarihi (Accepted): 8-01-2022

* Doç. Dr., İstanbul Üniversitesi Edebiyat Fakültesi Çağdaş Türk Lehçeleri ve Edebiyatları Bölümü (Istanbul University Faculty of Letters Department of Contemporary Turkish Dialects and Literatures) Turkey. reyila. kasgarli@istanbul.edu.tr. ORCID 0000-0003-1905-2022 
Altın Dişli Köpek, Domuzlara Bayram gibi hikâyeleriyle Çağdaş Uygur Edebiyatına yeni bir soluk getirir. Hoşur'un hikâyeleri hâlihazırdaki sorunları, Çin işgalinin Uygurların toplumsal yaşamında bıraktığı izleri, mizahi bir üslupla dile getirir. Bıyık Macerası adlı hikâye, dünyadan tecrit edilen Doğu Türkistan'da yaşanan bazı sosyal sorunların tipik örneklerini yansıtması bakımından özel bir yere sahiptir. Bu çalışmada, metne dayalı inceleme yöntemi kullandım. Amacım, Bıyık Macerası'nın önemini ortaya koymak ve Doğu Türkistan konusunda farkındalık oluşturmaktır.

Anahtar sözcükler: Uygur hikâyeciliği, bıyık macerası, Memtimin Hoşur

\begin{abstract}
Story in Modern Uyghur Literature has started to develop at the beginning of the 20th century. The movement of realism gives its place to socialist realism after 1949. Uyghur story telling, which aroused through ironic stories in which dignitaries with no use for the society were criticized, was enclosed to the political limits due to the coup towards the enlightened started by the slogan Struggle Against Local Nationalizm in 1958. No significant work was published in the Culture Revolution taking place between 1966-1976. The pressure was released to some extent based on the development policy of China in 1980s. This added stories that are about historical figures and national values in Uyghur literature.

Memtimin Hoshur brought a breathe of fresh air to the Modern Uyghur Litureture with his stories such as Deli (Insane), Bıyık Macerası (Moustache Adventure), Kenarlı Bardak (Glass with Sides), Altın Dişli Köpek (Dog with Golden Tooth), Domuzlara Bayram (Feast for Pigs). The stories of Hoshur voices the current problems, the traces of the Chinese occupation on the social life of Uyghurs in a humorous style.

The story entitled Moustache Adventure has a special place in terms of reflecting some typical examples of the social problems happening in East Turkestan, which is isolated from the rest of the World. I used text-based research method in this study. My purpose is to exhibit the importance of Moustache Adventure and create awareness about East Turkestan.
\end{abstract}

Keywords: Uygur story telling, moustache adventure, Memtimin Hoshur

\title{
Extended summary
}

Literary texts based on the principle of narration dating back to ancient times, in Uyghur literature.

As the first narrative genres, epics come to life in myths and legends. Transition from verbal narration to writing by making a story, tale, hadith, anecdote, cenkname etc. way it develops. Although the past it is accepted that the modern story began to be seen in East Turkestan in the 1930s, although it is based on is done with the end of the Cultural Revolution and China's new policies for development. However, especially after 1978, new periodicals and printing houses are added to the existing periodicals. Through the Uyghurs 
World Literature magazine, famous foreign works are translated into New Uyghur Turkish. By having the opportunity to read, he meets famous works in world literature. Many stories are written about what happened during the process. Towards the end of the 20th century, the negative aspects of the society in contemporary Uighur stories mostly themes such as criticism, protection of national culture begin to be processed.

Writer Memtimin Hoşur was born in Gulca in 1944 to a family engaged in blacksmithing.

income (Ablimit Ismayil and Mahmutcan Islam, 1993: 646). mother and father at a very early age.

He lost his life in Gulca, at the primer school, which was considered the cradle of education at the time, and in the student dormitory. He continues his education in Ürümçi in 1962-196. He studied at Sincan University, Faculty of Language and Literature. Hoshur reveals his competence in the literary field in the works he wrote after 1980 . The story named Bıyık Adventure (Memtimin Hüşur, 1991: 20-29) published in the literary magazine Tarim Jornili is an indicator of the author's courage in choosing a topic and his unique style of expression, and brings a new breath to contemporary Uyghur storytelling.

The subject of the story: In the story; because the electric file of the slaughterhouse broke down,

Because of the problem the mustachioed worker had with thieves, who went to the market to sharpen his knives, all the mustachioed men in the town are under suspicion, the uneasiness of the mustachioed people, trimming his mustache in order not to be considered a criminal, being subjected to pressure, daily life changes in order are explained.

Perspective: The story presents the events to the reader with the hero's point of view in the first person (me) narrator. I; taking place in the plot of the story, but also the plot of the plot

It is the real hero who bears all the burden. Story; It informs the reader within the framework of the self's possibilities of seeing, hearing, living and knowing. Events unnamed hero

transferred to the reader through the eyes of the narrator. I; Since he takes himself as the axis, he highlights what he experiences, knows, hears and feels.

Time: The case time between the starting point and the ending point of the plot in the story is about two months. When the hero narrator hears that the mustaches have been marked, he gets nervous and cuts his mustache. He gives written statement about it. Two months later, he went back to the market.

He comes out and learns that his mustache adventure is over and that the manager of the market, who is questioning the mustache / mustache-cut men in the town, wears a fake mustache. In addition, concrete time was expressed by using the words expressing time in the story. For example: morning, night etc. In the policy carried out in East Turkestan, discourse and practice are completely different from each other. Management constantly emphasizes 
how merciful it is to the people. in practice on the contrary, it is the opposite. For example, the Chinese believe that 20 points are added to the Uighurs in the university exam because they are a minority, and they complain about this situation. However, Uyghurs have the right to study in departments such as sociology, physics, chemistry, and aeronautical engineering.

Chinese officials placed in Uyghur families have come to establish a so-called fraternal bond and will help the families. In reality, the men of the families are in captivity, and Chinese officials are assigned to spy on families, destroy national values, transform and rebuild society. Such examples can be multiplied. Another example of this situation in the Mustache Adventure is embodied in the market manager. Representing the regime and administration The manager of the bazaar tells the hero that he has grown a mustache in line with the opinion of his superiors. A mustache is a fake mustache, the watchman said. Moreover, the manager of the bazaar wore this mustache because of the public's reaction. Mustache Adventure has a special importance as it shares a very ordinary example of inhumane practices carried out in East Turkestan, which is isolated from the world. The author used

The language and style, the narrative techniques he used, the references he made with the satirical method and the messages he gave between the lines made the story even more valuable and carried it to a special place in Uyghur storytelling. The understanding of art and works of Hoşur by Uyghur and Chinese researchers. There are dozens of reviews and evaluation studies on it until 2017.

Yalkun Rozi was able to express the true value of the Mustache Adventure. The story has been widely shared on Uyghur websites despite its sensitive subject matter. It would not be an exaggeration to say that it was read by every literate Uyghur. After 2009, many Uyghur websites were closed for sharing such works, and the owners were imprisoned.

Since 2017, censorship has reached its peak and East Turkestan has been completely blockaded. Currently, Uyghur websites are open for entertainment and political propaganda purposes is used.

\section{Giriş}

İsmail Bey Gaspıralı’nın Kırım'da başlattığı Usul-i Cedid hareketi ve Türk Dünyası'nı asgari müştereklerde birleştirmeyi amaçlayan ideoloji, Rusya işgalindeki Türklerin yayımladığı çeşitli kitaplar, gazeteler ve dergiler aracılığıyla Doğu Türkistan'a da ulaşır. Özellikle Gaspıralı'nın 1883'te başlayıp yayın hayatını tam otuz üç yıl sürdürdüğü Tercüman gazetesinin, Şura ve Til Yariş gibi dergilerin Uygurların kültürel yaşamına büyük etkisi olmuştur (Komisyon, 2006a: 241). Türkistan'da yaygınlaşmaya başlayan Usul-i Cedid hareketi ile birlikte Uygurlar arasında meydana gelen eğitimde reform ve halkı uyandırma ve bilinçlendirme çalışmaları, toplumda geniş ölçüde benimsenir, bu fikirlerin mahsulü olarak gazetecilik ve yayıncılık işleri hızla gelişir (E. Tatlık, 2004: 51-56). Gazete ve dergilerin yayımlanması çağdaş Uygur edebiyatının gelişmesine önemli katkılar sağlar. 
Geçmişi çok eskilere dayanan anlatma esasına bağlı edebî metinler, Uygur edebiyatında ilk anlatı türleri olarak destan, mit ve efsanelerde hayat bulur. Şifahi anlatımdan yazıya geçiş yapılarak kıssa, masal, hadis, fikra, cenkname vb. şekilde gelişir. Geçmişi her ne kadar eskiye dayansa da modern hikâyenin Doğu Türkistan'da 1930'lu yıllarda görülmeye başladığı kabul edilir.

20. yüzyılın başında toplumsal yaşamdaki gelişmeler ve Doğu Türkistan'da patlak veren ayaklanmalar, Uygur edebî eserlerinde realist bir yaklaşımın benimsenmesine vesile olur (Nurmehemmet Zaman, 1984: 88). Seypidin Ezizi'nin Yétim Tohti "Yetim Tohti" adlı kısa eseri, modern anlamdaki ilk hikâye örneklerindendir. Çöçek’te yayımlanan Yéñi Hayat dergisinde Ezizi'nin Zamankul "Zamankul", Menzire "Manzara", Aççik Hatire "Ac1 Hatıra" adlı hikâyeleri okuyucularla buluşur. Ayup Mensuri’nin hayattaki olumsuz olayları anlattı̆̆ Barat Celligür "Barat Hırsız" (Muhammet Polat, 1985: 16), Lutpulla Mutellip'in 1942'de yazdığı Ecel Hudukuşida "Ecel Telaşında", Padişah Samurayliri Ėğir Halsiraydu "Padişah Samurayları Yorgunluk İçinde” gibi eserleri, Zunun Kadiri’nin Muellimniñ Héti “Öğretmenin Mektubu”, Küçükke Hucum "Köpek Yavrusuna Hücum”, İki Barmikim Bilen "İki Parmağımla", Măgdur Ketkende "Dermandan Kesilirken" gibi hikâyeleri dönemin önemli eserlerindendir (Komisyon, 2006a: 368).

1949 yılında Doğu Türkistan’ın, Çin Komünist Partisi yönetimindeki işgalci güçlerin idaresi altına girmesiyle birlikte Uygur edebiyatına, sosyalist realizm yerleştirilmeye başlar. Eserlerde; toprak sahibi olan fakirlerin sevinci, başkan Mao’ya, komünist partiye ve Çin halk kurtuluş ordusuna olan övgüler sıkça işlenir. Sarañ Sakaydi "Deli İyileşti”, Çénikiş "Çelikleşme", Sinak "Deneme" adlı hikâyeler bu yıllarda yazılır. Ablimit Mesudi'nin Sarañ Sakaydi "Deli İyileşti” adlı hikâyesinde Hidayetullah ve Davut tipi üzerinden bir önceki yönetimde toprak sahibinin çektirdiği eziyetler nedeniyle çiftçilerin yaşam haklarından mahrum kaldığı, çekilen eziyetlerden akıllarını yitirdikleri, komünist parti yönetimi gelince huzura kavuştukları ve sevinci anlatılır, yeni yönetim ve sosyalizm övülür. Zunun Kadiri'nin Çénikiş “Çelikleşme” adlı hikâyesinde ise eskiden tembel ve beceriksiz olan Metniyaz'ın komünist parti yönetiminde becerikli ve topluma yararlı bir kişi oluşu anlatılarak yeni yönetimin bireyler üzerindeki olumlu etkileri dile getirilir (Alimcan İnayet, 2009: 73-117). Çağdaş Uygur edebiyatında povest olarak adlandırılan uzun hikâyenin ilk örneği Erşidin Tatlik' in Sinak "Deneme" adlı hikâyesidir. Bu hikâye, Uygur çiftçilerinin kolhoz hayatını konu alır.

1956'da uygulanan “Tüm çiçekler eşit açmalı, tüm fikirler özgürce dile getirilmeli” sloganlı propaganda, çağdaş Uygur edebiyatına yeni bir bakış açısı getirir. Böylece Teyipcan Eliyev'in Valaktekkürüpnin Ölümi “Gevezenin Ölümü”, Mömin Sepiri'nin Kuluplanğan Ka-binet "Kilitlenen Oda", Rehim Kasim'in Başlik Çüşen Pabida "Amirin Bindiği Araba" gibi hiciv hikâyeleri yazılır ve topluma yararı olmayan mevki sahipleri eleştirilir. Fakat 1957'de yürütülen “Sağcılara Karşı Hareket”, 1958-1959'da yürütülen “Yerli Milliyetçiliğe Karşı Mücadele”de bu eserler karalanarak yazarlar cezalandırılır (Azad Sultan, 2001: 16). Böylece "Fikir Özgürlüğü" sloganıyla canlanan Uygur hikâyeciliğii, durgunluk dönemine girer. 
1961 'de Pekin yönetimindeki Zhu En-lai'nin “açılma ve anlatma” prensibinin devam ettirilmesi, edebiyat ve sanatta demokrasinin uygulanmasıyla ilgili konuşmasının ardından Erşidin Tatlik' in Halta Koçidin Yanğanda “Çıkmaz Sokaktan Dönerken”, Keyyum Turdi’nin Kizil Yultuzluk Şepke "Kırmızı Yıldızlı Şapka”, Ehet Turdi’nin Hayatnin Başlinişi "Hayatın Başlangıcı", Abla Ehmidi’nin Yéni Öyge Köçüş "Yeni Eve Taşınma” gibi hikâyeleri yazılır. 1962-1963'ten itibaren yürütülen “Sınıf Mücadelesini Asla Unutmamak Lazım” sloganı nedeniyle eserler, siyasî konulara sıkça yer vermeye başlar (Sultan, 2001: 14-18).

1966-1976 yılları arasında gerçekleşen Kültür Devriminde üslup, ikinci plana itilerek içerik birinci plana alınır, Uygur hikâyeciliği, diğer türler gibi kayda değer eserlerden yoksun birakilır (Komisyon, 2006b: 432).

Kültür Devriminin sona ermesi ve Çin'in kalkınma amaçlı yeni politikalar izlemesiyle birlikte, özellikle 1978 'den sonra, mevcut süreli yayınlara ve basımevlerine yenileri eklenir. Uygurlar Dünya Edebiyatı dergisi aracılığıyla ünlü yabancı eserleri Yeni Uygur Türkçesiyle okuma firsatı elde ederek dünya edebiyatındaki ünlü eserlerle tanışır. Bu dönemde Devrim sürecinde yaşananların anlatıldığı birçok hikâye yazılır. Ablimit Sabir'in Unin Makani “Onun Mekânı”, Ehet Turdi’nin Merhaba Bă̆ven "Merhaba Öğretmen”, Zordun Sabir'in Kerzdar "Borçlu”, Kobulhanida "Görüşme Odasında", Dolan Yaşliri “Dolan Gençleri”, Kadir Arslan'ın Titrigen Avaz "Titreyen Ses” adlı hikâyesi Devrim'i konu alan hikâyelerden bazılarıdır (Komisyon, 2006b: 437). Ayrıca tarihî olayların, vatansever kahramanların konu edildiği hikâyelerin de yazıldığı görülür. Teyipcan Hadi’nin 1980'de yayımlanan Palvan Keldi "Pehlivan Geldi”, 1987'de yayımlanan Közümni Ėçip Çiktim "Gözümü Açıp Çıktım” adlı hikâyelerinde Sadır Pehlivan; 1987'de yayımlanan Batur Keldi "Bahadır Geldi” adlı hikâyesinde ise 1944 yılındaki millî kurtuluş savaşının kahramanlarından Geni Batur’u ve savaştaki kahramanlığı konu alır. Bu döneme damga vuran örnek eserlerden biri, Milliyetçi Çin Partisi döneminde Uygur halkının yaşadığı zorlukların ve boyun eğmeyen bir karakterin anlatıldığı Möminnin Momiğa Çikişi "Mömin'in Göndere Tırmanışı” adlı hikâyedir. Bu hikâye sözde çift dilli eğitimin uygulanmaya başladığı 2000 yılına kadar, ortaokul edebiyat ders kitaplarında yer alır.

Çağdaş Uygur edebiyatında Nurmuhemmet Tohti’nin kaleme aldığı Éşip Kalğan Bir Namrat "Geride Kalan Bir Yoksul", Zohregül Abduvahit'in kaleme aldı̆̆ 1 Ahirki Küz "Son Sonbahar" gibi köy yaşamının, köylerde yapılan reformların ve bu reformların çiftçilere etkisinin işlendiği hikâyeler de önemli bir yer tutar.

20. yüzyılın sonlarına doğru çağdaş Uygur hikâyelerinde çoğunlukla toplumdaki olumsuzlukları eleştirme, millî kültürü koruma gibi temalar işlenmeye başlar. Muhammet Eli Zunun'un Koş Mesçit “Çift Mescit”, Kahar Niyaz'ın Heyt "Bayram”, Halide İsrail'in Yıltız “Kök”, Ehtem Ömer'in Uykuluk Seher "Uykulu Seher”, Tohti Ayup'un Böşük "Beşik” adlı hikâyeleri bu tür eserlerdendir. Aynı zamanda kahramanların psikolojik durumlarını yansıtan, toplumsal bunalımları ve toplumsal bozuklukları, sistemin toplum üzerindeki etkilerini edebî seviyede işleyen eserler de meydana gelir. Ehtem Ömer, Memtimin Hoşur, Abbas Moniyaz 
Türkiykan, Calalidin Behram, Mahmut Muhemmet, Halide İsrail, Perhat Tursun, Ebeydulla İbrahim gibi yazarlar, bu konuları işleyen önemli isimlerdir. Memtimin Hoşur, hikâyeleri ile Uygur edebiyatında çı̆̆ır açan bir yazar olarak özel bir yere sahiptir.

\section{Memtimin Hoşur'un hayatı ve eserleri}

Yazar Memtimin Hoşur 1944 yılında Gulca' da demircilikle uğraşan bir ailede dünyaya gelir (Ablimit İsmayil ve Mahmutcan İslam, 1993: 646). Anne ve babasını çok erken yaşta kaybettiği için Gulca'da, döneminin eğitim beşiği sayılan İli Okulunda, öğrenci yurdunda kalarak eğitimini sürdürür (Abdulvahit Hasancan, 2016: 3). 1962-1967 yıllarında Ürümçi'de Şincan Üniversitesi Dil ve Edebiyat Fakültesinde eğitim görür (İsmayil ve İslam, 1993: 646).

Hoşur'un mezun olduğu dönem Kültür Devrimine denk geldiği için edebiyat dışı mesleklerde çalışır (Hasancan, 2016: 3). 1976 yılında Kültür Devriminin son bulmasıyla edebiyat sahasına döner, 1979 yılında İli Kazak Özerk İlçesi Edebiyat ve Sanatçılar Derneği tarafından çıkartılan İli Deryasi dergisinde editörlük ve baş editörlük gibi görevlerde bulunur ve 1994 yılına kadar bu gazetede çalışmaya devam eder. 1995 yılında Uygur Özerk Bölgesi Yazarlar Cemiyetinin 5. Kurultayı ve 2000 yılında 6. Kurultayında Şincan Uygur Özerk Bölgesi Yazarlar Cemiyetinin başkanlığına, 1996 yılında Şincan Özerk Bölgesi Edebiyatçılar ve Sanatçılar Derneğinin 5. Kurultayında ve 2002 yılı 6. Kurultayında derneğin başkan yardımcılı̆̆ına getirilir (Komisyon, 2006c: 663). Memtimin Hoşur, 1999 yılında Çin Yazarlar Cemiyeti tarafından "münevver 100 yazar"dan biri seçilir (Hasancan, 2016: 7).

Memtimin Hoşur'ın edebiyata olan ilgisi küçük yaşlarda başlar. Bu dönemlerde okuduğu çok sayıda eserin zihin dünyasında oluşturduğu etkilerle yazarlık dünyasına adım atar. $\mathrm{Bu}$ konuda yazar, "1949 sonrası Rus, Arap ve Hint yazarların bazı eserlerini Uygurca olarak okuma şansım oldu. Bu eserler beni derinden etkiledi.” demektedir (İsmayil ve İslam, 1993: 646-647). Hoşur gene "İyi yazılan eser, klymetli bir ders gibidir. Ondan pek çok şey öğrenilir” der (youtube: 01.12.2020). Belki de bu yaklaşım, Hoşur'un hikâyelerindeki konu seçiminde etkili olmuştur. Yazar aynı zamanda Türkiye yazarlarından Aziz Nesin'in hikâyelerini okuduğunu ve bu hikâyelerin kendi edebî üretimi üzerinde etkili olduğunu belirtmektedir (Hasancan, 2016: 5).

Memtimin Hoşur, edebî faaliyetlerine ortaokulda okuduğu dönemlerde başlar. Bu yıllarda bazı şiirleri Şincañ Ösmürliri gazetesinde yayımlanır (Azad Sultan ve Kerimcan Abdurehim, 2002: 226). Şiirlerin dişında pek çok hikâyesi ve uzun hikâyesi Tarim, Tenrită̆, Şincang Medeniyiti, İli Deryasi gibi çeşitli dergilerde yayımlanır (Hasancan, 2016: 3). Bu hikâyeler ve uzun hikâyeler sonraki dönemlerde Ney Avazi "Ney Sesi" (1982), Kona Yeni İşler "Eski Yeni İşler”, Salam Hesam Aka “Selam Hesam Ağabey” (1989), Ölükke Het “Ölüye Mektup” (1993), Nuzugum, Ot Ketken Derya “Alev Almış Derya” (2001), Bu Çüş Emes “Bu Düş Değil” (1991), Memtimin Hoşur Hikayiliridin Tallanmilar "Mehmet Emin Hoşur Hikâyelerinden Seçmeler", Memtimin Hoşur Povistliridin Tallanmilar "Mehmet Emin Hoşur Uzun Hikâyelerinden Seçmeler" adlı kitaplarda toplanarak yayımlanır (Hasancan, 2016: 3-4). 
Bazı hikâyeleri Kona-Yeni İşlar "Eski-Yeni İşler” (1987), Seğiniş “Özlem” (1984), Sovğat "Hediye" (1985), Kutluk Keçe "Kutlu Gece" (1992) adlı antolojilerde yer alır (Eziz Atavulla Sartekin, 2006: 9-12). Bunun dışında Yillar Şundak Ötken "Yıllar Böyle Geçmişti" (1989), Kum Baskan Şeher "Kumun Bastığı Şehir” (1996), Salçilar "Sandalçılar” (2012) adlı romanları; Yillar Şundak Ötken "Yıllar Böyle Geçmişti” (2005) adlı hatırası ve başka yazarlarla birlikte düzenlediği Uyğur Helk Letipiliri "Uygur Halk F1kraları" adlı eserleri bulunur. (Sartekin, 2006: 29-34; Hasancan, 2016: 3-4).

Bütün bu çalışmalarının yanında Memtimin Hoşur, Uygur makamları, İli halk şarkıları ve İli tarihi üzerine araştırmalar yapmış ve çeşitli ilmî eserler ve makaleler yayımlamıştır (Komisyon 2006c: 666-667).

Memtimin Hoşur'ın Bu Çüş Emes "Bu Düş Değil”, Burut Macirasi "Bıyık Macerası" ve Ustazim "Hocam" hikâyeleri, Savakdaşlar "Sınıf Arkadaşları" uzun hikâyesi ve Ölükke Het "Ölüye Mektup" kitabı Münevver Eser Ödülü’ne; beş hikâyesi Hantanrı Edebiyat Ödülü’ne layık görülür (Komisyon, 2006c: 666). Bunun dışında birçok eseri Tarim Edebiyat Ödülü ve Gülzar Edebiyat Ödülü’ne layık görülür (Hasancan, 2016: 7). Buğa "Boğa” hikâyesi 1985 yılı Çin Yeni Edebiyat Sözlüğü’nün Azınlık Milletler Eserleri kısmında yer alır; Sinaş, Ney Avazi, Yiraktin Yezilğan Het, İkki Parçe Het, Dehkan, Kona-

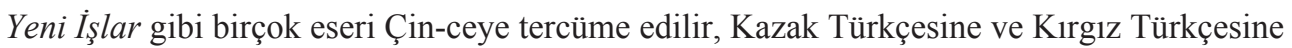
aktarılır ve birçok edebiyat araş-tırmacısı tarafından incelenir (İsmayil ve İslam, 1993: 648)Burut Macirasi hikâyesi İngilizceye (Hasancan, 2016: 7) ve Türkiye Türkçesine aktar1lan (Münever Aksu, 2016: 225-256) bir hikâyedir.

\section{Bıyık macerası adlı hikâyenin tahlili}

Hoşur, edebî sahadaki yetkinliğini 1980'den sonra yazdığı eserlerinde ortaya koyar. Edebî dergi olan Tarim Jornili'nda yayımlanan Bıyık Macerası (Memtimin Huşur, 1991: 20-29) adlı hikâye, yazarın konu seçimindeki cesaretinin, kendine özgü anlatım tarzının bir göstergesi olmakla beraber çağdaş Uygur hikâyeciliğine yeni bir soluk getirir.

Hikâyenin konusu: Hikâyede; mezbahanın elektrikli eğesi bozulduğu için kasapların bıçaklarını biletmek üzere çarşıya çıkan bıyıklı işçinin hırsızlarla yaşadığı sorundan ötürü, kasabadaki bütün bıyıklı erkeklerin zan altında bırakılması, bıyıklı insanların yaşadığ 1 tedirginlik, suçlu sayılmamak için bıyıkları kestirmesi, baskıya maruz kalması, günlük yaşam düzenlerinin değişmesi anlatılır.

Olay örgüsü: Hikâye iç içe yerleştirilmiş iki hikâyeden oluşur. Bir kişinin, editör olan kahramana onun adıyla yayımlanmasını istediği eserini getirmesiyle başlar. Kahramanın müsveddede bulunan hikâyeyi okumasıyla da ikinci hikâyeye- esas hikâyeye- geçilir.

Bıyık bırakanların fişlendiğini duyunca tedirgin olan kahraman, mahallenin bekçisi Ömercan'dan fişlenmeye sebep olan olayı öğrenir. Birkaç gün önce çarşıda pala bıyıklı, uzun boylu biri güpegündüz elinde bıçakla adam öldürmeye kalkışmıştır. Çarşı yöneticisi bizzat bu olayı araştırmaktadır. Kahraman, bıyıkları şüphelinin bıyıklarına benzemediği 
için şükrederken boyunun uzun oluşunun benzemesi nedeniyle hâlâ tedirgindir. Evine dönüp oğlu Ahmetcan'ın bıyıklarının gür olduğunu fark edince babalık otoritesini kullanarak oğlunu berbere götürür ve baba oğul sinekkaydı tıraşı olur, baş belası bıyıklarından kurtulur. Bu sırada İsmail Berber, bugün toplam yirmiden fazla kişinin bıyıklarını kestirdiklerini dile getirirken sinsice gülümser. Kahraman, berber tarafından takip edilme ihtimalini düşünerek huzursuz olur. Akşam eve bekçi Ömercan gelir ve kahramanın bıyıklarını kestirdiğini çarşı yöneticisinin öğrendiğini, bu nedenle yarın sabah hükümet konağına gitmesi gerektiğini söyler. Çarşı yöneticisi yeni gelmiş biridir ve çok sinirli olduğu söylenmiştir. Kahraman daha da huzursuz olur. Akşam eşinin örgü örerken anlattıkları kulağına girmez. Dalgındır, huzursuzdur, endişelidir. Gece uyuyamaz. Sabaha karşı kâbus görür ve çığlık atarak uyanır. Eşine rüyasını anlatır. Rüyasında eşinden kendisini söküp yeniden örmesini ister. Karısı, söküp yeniden örünce kopmuş, bozulmuş yerleri çıkartacağı için küçüleceğini söyler. Kahraman, küçülmenin daha iyi olacağını dile getirir. Eşi, onu ayak parmaklarından başlayarak söker ve boğazına gelince ip dügüumlenir, boğulmaya başlar, çığlık atar ve uyanır. Eşi bu rüyayı duyunca kahkahalarla güler. Çünkü eşi, çarşıdaki olayları ve kahraman ile oğlunun bıyıklarını neden kestirdiğini bilmemektedir.

Kahraman hükümet konağına gider. Orada Bekçi Ömercan’a ve çarşı yöneticisine olayı anlatmakta olan kişinin söylediklerinden çarşıdaki bıyıklıya ilişkin olayın detayını öğrenir. Birkaç gün önce- Pazar günü- üç genç bir kişiyi döverler. Dövülen adam bir anda biçak sallar. Arkadan yanaşan bir kişi onun elinden bıçağı alır. Dövülen adam ikinci bıçağı çıkarır. Bu bıçağ1 da alınca üçüncü bıçağı çıkarır. Bunun üzerine çarşıda bir kaçış başlar. Olayı anlatan görgü tanığı da kaçtığı için olayı buraya kadar görmüştür. Çarşı yöneticisi bıçaklının eşkâlini detaylı bir şekilde yazarak yarın getirmesini söyler. Sonra kahramana bıyıklarını neden böyle apar topar kestirdiğini sorar. Kahraman, Ömercan'dan duyduklarından sonra tedirgin olduğunu söyleyemez. Başka bahane uydurur. Çarşı yöneticisi, olay sonrası çarşı1da bulunan çantada otuz kırk kadar bıçak görüldüğünü, bu olayın basit bir olay olmadığını, duyduğuna göre binlerce yıl öncesinde İskender adlı biri ordusuyla birlikte buralara ulaştığında bir sürü bıçakçıyla karşılaşarak zorluk yaşadığını, yüzlerce yıl önce Cengizhan buradan geçerken sayısız bıçakçının onların safına katıldı̆̆ını anlatır.

"Bu bıçakçıların bakmadan attığı bıçaklar, karşıdan gelenin tam alnına saplanıp onu yere seriyormuş. Bugün aramızda yine böyle bıçakçılar güçlenmeye başlıyormuş gibime geliyor. Onların başımıza bir felaket açmayacağını kim söyleyebilir?” (Aksu, 2016: 245).

$\mathrm{Bu}$ nedenle kahramanın eve dönüp bıyıklarını ne zaman bıraktığını, neden kestirdiğini, şekli şemasını ayrıntılı yazarak yarın sabah teslim etmesi gerektiğini vurgular.

Kahraman akşam evinde bıyığının tarihini yazmaya çalışır. Gece gene kâbus görür. Bu sefer rüyasında çamaşır makinesinde dönmektedir. Ertesi öğlene doğru bıyığının tarihi yazılı kâğıdı hükümet konağına götürdüğünde bıyık gerekçesiyle sorguya çekilmekte olan kişileri görür. Kâğıdı teslim edip çarşıya gider. Esnafın çeşitli boy ve şekildeki bıçaklarını görür. Kahramanın ruh sağlı̆̆ bozulmuştur, olayları ve insanları rüyasıyla ilişkilendirerek düşünmeye başlar. 
Kahraman iki ay boyunca dışarı çıkmaz. Nihayetinde alışverişe çıktığında okkalı bıyık bırakmış olan çarşı yöneticisi ile karşılaşır. Çarşı yöneticisi kahramanı tanımaz. Çünkü kahraman gibi birçok kişiyi sorguya çektiğinden kahraman onun aklında kalmamıştır. Kahramanın hatırlatması üzerine çarşı yöneticisi, olayın aslını anlatır. Mezbahanın elektrikli eğesi bozulduğu için kasapların bıçaklarını biletmek üzere çarşıya gidecek olan bıyıklı işçiyi, üç hırsız sıkıştırır ve parasını çalar. İşçi parasının çalındığını fark edince otobüsten inerek hırsızların yakasına yapışır. İşçi kekemedir. Ne toplanan kalabalığa derdini anlatabilir ne de hırsızları bırakır. Hırsızlar onu dövüp kaçmak isterken o bıçakları çıkarır.

Çarşı yöneticisi, olayı çok derin analiz ettiğini, büyütülecek bir şey olmadığını, amirlerinin kendisi hakkında "ezelden bıyıklılara karşı önyargılı biriydi”" demesi üzerine bıyık bıraktığını söyler. Meğerse çarşı yöneticisi köseymiş ve sahte bıyık yapıştırmış. Kahraman, dünyanın böyle ilginç hallerinin olduğuna şaşakalır. Hikâye burada son bulur.

Bakış Açısı: Hikâye olayları, kahraman bakış açılı birinci tekil kişi (ben) anlatıcı ile okuyucuya sunmaktadır. Ben; hikâyenin olay örgüsünde yer alan, aynı zamanda olay örgüsünün bütün yükünü üstlenen asıl kahramandır. Hikâye; Ben'in görme, duyma, yaşama ve bilme imkânları çerçevesinde okuyucuyu bilgilendirmektedir. Olaylar ismi zikredilmeyen kahraman anlatıcı gözünden okura aktarılır. Ben; kendini eksen aldığı için kendisinin yaşadıkları, bildikleri, duydukları ve hissettiklerini öne çıkarmaktadır. Örneğin:

"Bir anda hükümet konağına gitme işi aklıma geldi. Aceleyle giyindim." (Aksu, 2016: 239). "Kalbim yerinden çıkacak gibi attı. Sıska arkadaş beni baştan aşağı süzdükten sonra, "Hayır, hayır, bu kişiden daha uzun diye düşünüyorum." dedi. "Oh" diye derin bir nefes aldım. Sıska arkadaş gözüme bir başka sempatik görünmeye başladı" (Aksu, 2016: 241).

Kişiler: Hikâyede anlatılan olayları var eden ve yaşayan kişileri aşağıdaki gibi listelemek mümkündür.

Anlatıcı (ben): Kahraman anlatıcıdır. Giriş hikâyesindeki kahraman (ben), editördür. Bir yazarın hikâyesini onun isteği üzerine kendi adıyla yayımlatmak üzere teslim alır ve okumaya başlar. Editör olan ben'in okumasıyla başlayan ikinci hikâyedeki- esas hikâyedeki- kahraman; uzun boylu ve bıyıklıdır, evli ve bir erkek çocuğun babasıdır.

Hanım: Kahraman anlatıcının karısıdır. Yırtılmış ve eskimiş yün kıyafetleri söküp, ipleri top haline getirir ve şiş ile örgü örer. Aynı zamanda eşine, duyduğu mahalle dedikodularını anlatır.

Ahmetcan: Kahraman anlatıcının oğludur. Bıyıklarının kesilmesini istemediği halde babasını kıramayıp tıraş olur.

Bekçi Ömercan: Çarşıdaki olayları kahramana anlatır. Çarşı yöneticisinin emirlerinin ulaştırır.

İsmayil Berber: Kasabada bir günde yirmiden fazla kişinin bıyığını keser ve bu duruma şaşırır.

Çarşı yöneticisi: Kısa boylu, kilolu bir adamdır. İnsanların üzerinde baskı kurar. Fakat amirlerine karşı çok itaatkârdır. Yuvarlak kahraman olarak tanımlanabilecek bir tiptir. 
Hikâyeyi anlamlı kılan, bu yuvarlak kahramanın var oluşu ve tip niteliği taşımasıdır. Zira modern roman ve hikâye, büyük ölçüde yuvarlak kahramanın ekseninde vücut bulur (Forster, 1982: 119). Bıyık Macerası'nı mizahi yapıya büründüren unsurlardan biri, çarşı yöneticisinin en büyük tehlike olarak gördüğü bıyıklara sahip oluşudur.

Zaman: Hikâyede olay örgüsünün başlama noktası ile bitiş noktası arasında geçen vaka zamanı, iki ay kadar süredir. Kahraman anlatıcı bıyıklıların fişlendiğini duyunca tedirgin olur, bıyığını kestirir. Bununla ilgili yazılı ifade verir. Aradan iki ay geçtikten sonra tekrar çarşıya çıkar ve bıyık macerasının sona erdiğini hatta kasabadaki bıyıklı/ bıyığını kestiren erkekleri sorguya çeken çarşı yöneticisinin sahte bıyık taktığını öğrenir. Ayrıca hikâyede zaman ifade eden sözcükler kullanılarak somut zaman ifade edilmiştir. Örneğin: sabah, gece vs.

Mekân: Hikâyede güçlü bir mekân-insan ilişkisi göze çarpar. Çarşı yöneticisi, hükümet konağında insanlara emir verir, sorgu gerçekleştirir. Onun otoritesi, mekândan ötürü güçlüdür. Kapalı ve açık mekânlar, kişilerin karakterinin şekillendirilmesinde önemli bir fonksiyona sahiptir. Kapalı mekânlar: ev, hükümet konağı şeklinde geçer. Hükümet konağ1, çarşı yöneticisinin karakterinin açığa vurulduğu bir yerdir. Ev ise kahraman anlatıcının sökme-örme işlemiyle boyunu kısaltarak kendini kurtarmayı hedeflediği bir ortamdır. Bilinçaltına yerleşen bu fikir, rüyasında gerçekleşir. Açık mekânlar: sokak, çarşı olarak geçmektedir. Kahraman anlatıcının çarşı yönetici ve bekçi ile karşılaşması sokakta gerçekleşir. Bıyık macerasının düğüm noktası ise çarşıdır. Ancak bu mekânlarla ilgili betimlemelere yer verilmemiştir. Bu durum, hikâyenin daha çok olaylara odaklanmayı tercih etmesiyle açıklanabilir.

\section{Bıyık macerası adlı hikâyenin önemi}

Bıyık Macerası, tıpkı Sarañ "Deli”, Kırlık İstakan "Kenarlı Bardak”, Altun Çişlik It “Altın Dişli Köpek", Çar Horaz "Renkli Horoz" adlı hikâyeler gibi yazarın kendi üslubunu sergileyen bir eserdir. Hikâye, iç içe kurgulanmış iki hikâyeden oluşmaktadır. Deli, Kenarlı Bardak gibi hikâyeler de aynı şekilde başlamaktadır. Bu eserler, okuyucuya sanki birbiri ile ilişskili bir seri hissini verir. Aslında esas hikâye birbirinden farklıdır. Bu farklı hikâyelerin ortak yönü ise, Uygurların sosyal hayatının birer aynası niteliği taşımasıdır. Bu hikâyelerin belli bir giriş yapısının oluşu, gelişme ve sonuç bölümlerinden meydana gelmesi, olay örgüsü üzerine kurulu olması ve bir takım iniş çıkışlarla okuyucunun merakının canlı tutulması, yazarın Maupassant tarzını benimsediğini göstermektedir. Zira Maupassant tarzı hikâyede hayattaki çatışmalar, yoğunlaştırılarak metne taşınır. Olay örgüsünün bitmesi ile birlikte, kurulan itibarî âlemdeki hayat da sona erer. (İsmail Çetişli, 2009: 28).

Bıyık Macerası'nın esas hikâyesi şu cümlelerle başlar. "Bıyık bırakanları fişliyorlarmış, diye duyunca şaşırdım. Nüfus kaydı olmayanları, mahallede okuma yazma bilmeyenleri veya çöp vergisi ödemeyenleri fişlediklerini görmüştüm” (Aksu, 2016: 229). Bu cümleler, Uygurların hayatında fişleme olayının çok sık yaşandığına işaret etmektedir. "Bir zamanlar sakal ve bıyık bırakanların zorla tıraş edilmesi gibi olaylar yaşanmıştı, yine böyle kâbus gibi günler geri mi geldi ne?” (Aksu, 2016: 229) cümlesiyle yazar, daha önce yaşanan toplumsal bask1lara gönderme yapmaktadır. Nitekim Çanışev, bu durumun kızlar üzerindeki uygulamasını 
şöyle dile getirmektedir. "Okul yönetimi bir duyuru yaptı. Müslüman kızlar da saçlarını Çinli kızlarınki gibi kısa kestirsinler” (Süyüngül Çanışev, 2016: 23). Günümüzde yaşlı dedelerin bile sakal bıyıklarına izin verilmediğini biliyoruz. Bu uygulamadan hareketle hikâye, Doğu Türkistanlıların günlük yaşamında dış görüntüye dek periyodik bir baskıya ve değiştirmeye maruz bırakıldığını ifşa etmektedir.

İşgal altında yaşayan toplumda huzur yoktur. Hikâyede insanların tedirgin ruh hali, kahraman anlatıcı özelinde örneklendirilmiştir. Kahraman, bıyıklıların fişlendiğini duyunca endişeli ruh halini şu cümlelerle ifade eder. "Durup dururken kendi kendime endişelenmeye başladım"; "Boyumun uzunluğu başıma iş mi açacak ne?" (Aksu, 2016: 229). Kahraman, berberin, kendisi gibi bıyığını kestirenleri takip ettiğinden şüphelenir. Kahramanın şüpheci yaklaşımı, toplumda oluşan güvensizliği açığa vurmaktadır. Bekçi Ömercan’ın “Bıyıklarınızı kestirmeniz, çarşı yöneticisinin kulağına gitmiş.” cümlesi, jurnal etmenin boyutunu göstermesi bakımından önemlidir.

Kahramanın rüyasında, kendisinin örgü yapılmak üzere sökülmesini görmesi, sembolik bir anlam ifade etmektedir. Kahraman sadece rüyasında değil, günlük yaşamda da birine baktığında onu söküp tekrar örünce nasıl olacağı hakkında düşünür. Bu hususta ünlü eleştirmen Rozi görüşlerini şöyle dile getirmektedir.

\footnotetext{
“Tekrar tekrar sökülüp örülme-yeniden inşa edilme, yapılandırılma- gibi bahtsız kader, bu bıyıklıları endişeli bir duruma getirmiştir. Söküp yeniden örmekteki amaç, istediği şekle sokmaktır. İnsanı kendi isteklerinden, yaşam tarzından, inanışından yoksun bırakan bu tür sökme-örme ne kadar da korkunç. Bu açıdan bakıldığında "ben"in endişesi ve korkusu komik ve ilginç gelmez. Tam tersine yüreklere acı verir" (Yalkun Rozi, 1991: 145)
}

Bu tür yeniden yapılandırma, hikâye yazılmadan önceki dönemlerde toplumsal düzeyde uygulanmıştı. 1944 yılında kurulan Doğu Türkistan Cumhuriyeti’nin millî ordusu, 1949 yılından sonra yeniden yapılandırılmış, tasfiye edilmişti (Sopahun Süvürof, 2010: 496). 1957 yılında "Yaşam Tarzını Düzeltme Harekâtı" kapsamında toplumsal bir yapılandırma uygulanmıştı (Çanışev, 2016: 17-20). Kültür Devrimi’ndeki aydın katliamı, yazılı kaynakların tahribi, pin-yin temelli Latin alfabesine geçiş gibi uygulamalar, birer sökme-örme örneğidir. Hikâye, toplum üzerindeki çeşitli yapılandırmaları kahramanın rüyası ve düşünceleri aracılığıyla sembolik olarak açığa vurmaktadır. Günümüzde bu yapılandırmayı Doğu Türkistan’ın mimari dokusu, aydınların tutuklanması, Uygurcanın yasaklanması gibi birçok örnekte görmek mümkündür.

Hikâye, rejimin halk üzerindeki baskısını çarşı yöneticisi özelinde okuyucuya aktarır. Çarşı yöneticisi, kasabaya yeni atanmış bir memurdur. Kulağı delik, istediği kişiyi sorguya çekebilen, istediği şekilde emirler veren bir adamdır. Onun baskısına maruz kalan sadece kahraman anlatıcı değildir. Çünkü kahraman geldiğinde "Bina içinde bıyık gerekçesiyle çağrılmış birkaç kişi daha sorguya çekiliyordu” (Aksu, 2016: 249). Ayrıca halk, anlamsız işlerle meşgul edilir. Çarşı yöneticisinin "Eve dönüp bıyıklarınızı ne zaman bıraktığınızı, niçin kestirdiğinizi, bıyıklarınızın şeklini, şekli derken kaytan bıyık mı, pala bıyık mı, burma bıyık mı 
yoksa pos bıyık mı, hepsini ayrıntılı yazarak en geç yarına kadar bize teslim edin!” (Aksu, 2016: 245) diye emretmesi üzerine kahramanın, bıyığının doğumundan ölümüne kadar olan hikâyesini yazması, halka çektirilen bir çeşit eziyettir. Çarşı yöneticisi tarih bilgisine sahip bir insan değildir. Kulaktan dolma bilgileri-bıçakçılarla ilgili tarihî hikâyeleri- anlatarak, bıçakçıların ne denli tehlikeli insanlar olduğunu ifade etmeye çalışır. Çarşı yöneticisinin bu davranışı, kendi tarihini öğrenme hakkından mahrum bırakılmış bir toplumun durumunu gözler önüne sermektedir. Çarşı yöneticisi, halka baskı uygulayan biri olmasına karşın amirlerine son derece itaatkârdır. "Amirlerin görüşlerine dikkat etmek gerekiyor" (Aksu, 2016: 253) cümlesiyle üstlerine yaranma kaygısı taşıdığını belirtir. Bıyıklılara karşı önyargılı olmadığını amirlerine kanıtlamak amacıyla sahte bıyık takması onun, halkına karşı gaddar, yönetime karşı köle ruhlu bir yönetici olduğunu gösterir. Burada gene ince bir göndermeyi sezinliyoruz.

Doğu Türkistan' da yürütülen politikada söylem ile uygulama, birbirinden tamamen farklıdır. Yönetim, halka ne kadar merhametli davrandığını sürekli olarak vurgular. Uygulamada ise tam tersine hareket edilir. Örneğin, Çinliler üniversite sınavında Uygurlara azınlık olmasından dolayı yirmi puan eklendiğine inanırlar ve bu durumdan şikâyetçiler. Oysa Uygurlar sosyoloji, fizik, kimya, uçak mühendisliği gibi bölümlerde okuma hakkına sahip değillerdir. Uygur ailelerine yerleştirilen Çinli memurlar, sözde kardeşlik bağı kurmaya gelmişlerdir ve ailelere yardım edeceklerdir. Gerçekte ise ailelerin erkekleri tutsaktır ve Çinli memurlar aileleri gözetlemek, millî değerleri yok etmek, toplumu dönüştürmek ve yeniden inşa etmek için görevlendirilmiştir. Bu tür örnekler çoğaltılabilir. Bıyık Macerası'nda bu durumun bir başka örneği, çarşı yöneticisinde vücut bulmuştur. Rejimi ve yönetimi temsil eden çarş1 yöneticisi, kahramana, amirlerinin görüşü doğrultusunda bıyık bıraktığını anlatır. Bekçinin söylediğine göre bıyık, sahte bıyıktır. Üstelik çarşı yöneticisi bu bıyı̆̆ı, halkın tepkisi nedeniyle takmıştır.

Çarşı yöneticisinin “Aramızda yine böyle bıçakçılar güçlenmeye başlıyormuş gibime geliyor. Onların başımıza bir felaket açmayacağını kim söyleyebilir?” (Aksu, 2016: 245) cümleleri, yönetimin Doğu Türkistan halkının güçlenmesinden ve kendilerine karşı gelmesinden çok korktuklarının bir ifadesidir. Halkın karşı gelmesi ve ayaklanması, yönetim için bir felakettir. Yönetim, başlarına böyle bir felaketin her an gelebileceğinden endişelidir. Bu nedenle çarşıda bir bıyıklının bıçak salladığını duyunca işin aslı astarı henüz belli olmadan bütün kasabadaki bıyıklıları fişlemeye başlar ve sorguya çeker. Hikâye, yönetimin bu korkusunu bıyık motifi üzerinden dile getirir. Son zamanlarda Doğu Türkistan'da bütün evlerdeki ve işyerlerindeki bıçakların fişlendiği hatta zincirle sabitlendiği gerçeği, yönetimin korkusunun bıçak motifi üzerinden de anlatılabileceğini akıllara getirir. Hikâyede yönetim, bıyıklılardan korkar. Çünkü- çarşı yöneticisinin önyargısıyla- "Bütün bıyıklıların mutlaka bıçağı da olur" (Aksu, 2016: 243). Aslında bıyıklılardan korkmanın nedeni, onların bıçaklarının olmasıdır ve "bakmadan attıkları bıçakları, karşısındakinin alnına saplanıp, onu yere seriyor" (Aksu, 2016: 245) olmasıdır.

Hikâye, Doğu Türkistan'da halkın hiçbir suç işlemese de suçlu sayılabileceğinin altını çizmektedir. Kahraman anlatıcı, bıyığını kestirdiği için tıpkı bir suçluymuş gibi sorgu- 
ya çekilir. Saçma olduğunu bile bile bıyığının tarihini yazmaya mecburdur. Tıpkı Kültür Devrimi'nde yurtdışında akrabası olanların suçlu sayıldığ 1 gibi, tıpkı günümüzde yurtdışına çıkanların özellikle Türkiye'ye seyahat edenlerin hapse atıldı̆̆ı gibi.

Doğu Türkistan'da bir korku imparatorluğu kurulmuştur. İnsanların periyodik olarak fiziksel ve ruhsal işkencelere maruz kalması sonucu oluşan bu atmosfer, Muellimin Mektubu (Doğan 2021: 625-630) adlı hikâyede de dile getirilir. Korku, toplumda kuşaktan kuşağa yayılan sinsi bir hastalık gibidir. Bıyık Macerası'ndaki kahramanın, oğlunu zorla berbere götürmesi, bıyıklarıyla bir hatıra fotoğrafı çektirmesine bile izin vermemesi, kendisinde bulunan korkuyu oğluna bulaştırdığının bir ifadesidir. Kahraman, bıyığının tarihini yazılı olarak teslim ettikten sonra iki ay boyunca evinden dışarı çıkmaz. İşgalden kurtulmak için korkuyu yenmek gerekir. Nitekim Atatürk "Muhtaç olduğun kudret, damarlarında akan asil kandadır" demiştir. Hikâye, sinmemek ve hakları aramak gerektiğini bekçi Ömercan'ın sözleriyle hatırlatır. “Bu olayda herkes ona-çarşı yöneticisine- bıyıklılar sana ne yaptı, diye tepki gösterip canına okuduğu için, sanat merkezinden o takma bıyığ1 getirip takmış" (Aksu, 2016: 255). Halkın tepkisi, çarşı yöneticisine geri adım attırmış hatta halktan biri olarak görünmeye çalışmasını sağlamıştır. Bu noktada Abdülhamit Süleyman Çolpan'ın “Halk denizdir, halk dalgadır, halk güçtür” mısralarının anlamı ve önemi daha da pekişmektedir.

Hikâyenin 1991 yılında yayımlandığı dikkate alınırsa, bu tarihten önceki dönemlerde yaşanılan olayları özetlediği söylenebilir. Fakat Doğu Türkistan'ın günümüzdeki durumu göz önünde bulundurulduğunda ise, gelecekte olacakların betimlenmesidir denilebilir. Realist bir yaklaşımla kaleme alınan bu eser, Doğu Türkistan'ın durumunu bilmeyenler veya bağımsız, demokratik ülkelerde yaşayanlar için mizahi üslupla yazılmış ilginç bir hikâye olabilir. Ancak hikâyedeki olayın ve benzerinin tanıkları için ise, gerçek yaşamın edebî esere yansımasıdır.

Hikâye, Doğu Türkistanlıların hayatındaki sayısız trajikomik olaylardan birini yüksek edebî beceri ile okuyucuyla paylaşır. Bu nedenle Bıyık Macerası, çağdaş Uygur hikâyeciliğinde özel bir yere sahiptir. Yazarın sanat yeteneği ve konu seçimindeki cesareti ise takdire şayan bir başka husustur.

Hikâye, yer yer diyaloglarla örülü bir anlatım tekniğine, yer yer yorumlama / açıklama tekniğine başvurur. Aynı zamanda kahramanın kendisiyle sohbet edercesine geçen cümlelerinden yazarın iç diyalog tekniğini de kullandığı görülür. Dili sade ve akıcıdır. Cümle şekilleri ve ifade tarzı, sıradan insanların dil kullanım özelliklerini yansıtır.

\section{Sonuç}

Geçmişi her ne kadar eskiye dayansa da modern hikâyenin Doğu Türkistan'da 1930'lu yıllarda görülmeye başladığı kabul edilir. Çağdaş Uygur edebiyatında hikâyeler; benimsediği akım ve muhteva seçimi bakımından Çin'in Doğu Türkistan'da uyguladığı politika ile paralellik göstermektedir.

Yazar Memtimin Hoşur (1944- ), edebî yetkinliğini 1980 sonrası yayımlanan eserlerinde gösteren ve Moupassan tarzı hikâyeleri ile Uygur hikâyeciliğinde çığır açan bir aydındır. 
1949'dan sonra Uygurca yayımlanan Rus, Arap ve Hint yazarların eserlerinden etkilendiğini dile getirir. Eleştirmenlerin edebiyat akımları ve edebiyat teorisi gibi görüşlerine çok takılmadığını, içinden geldiği gibi yazdığını savunur. İncelediğimiz Bıyık Macerası adlı hikâyesi 1991 yılında yayımlanmıştır. Bu yıllar Uygurlar için, Çin'in 1978'den itibaren yürüttüğü kalkınma politikasına bağlı olarak bir ölçüde serbestliğin hâkim olduğu yıllardır. Zira Divanü Lügati’t Türk, Kutadgu Bilig, Uygur Tilining İzahlık Lügati, Turgun Almas’ın Uygur tarihini konu alan kitapları gibi birçok değerli eser, bu yıllarda yayımlanabilmiştir. Dolayısıyla Hoşur'un konu seçimindeki cesareti, hikâyenin Uygur toplumunda yaşanan sosyal sorunları ifşa etmesi, tesadüf değildir.

Bıyık Macerası'nda olaylar, kahraman anlatıcı tarafından anlatılır. Bu anlamda kahramanın, toplumsal sıkıntılara olan bakış açısının, hikâyenin kurgusuna yansıdığı söylenebilir. Hikâyedeki konu, günümüzde dillendirilmesine müsaade edilmeyen uygulamaların örneğidir. Hikâyede sosyolojinin konusu, edebiyat aracılığıyla dile getirilmiştir. Yazar sosyal sorunları dile getirerek adeta kapalı kutu haline getirilen Doğu Türkistan'da yaşananları bir nevi ifşa etmiştir.

Bıyık Macerası, dünyadan tecrit edilen Doğu Türkistan'da yürütülen insanlık dışı uygulamaların çok sıradan bir örneğini paylaşması nedeniyle ayrı bir öneme haizdir. Yazarın kullandığı dil ve üslup, başvurduğu anlatım teknikleri, hiciv yöntemiyle yaptığı göndermeler ve satır aralarında verdiği mesajlar, hikâyeyi daha da kıymetli kılmıştır ve Uygur hikâyeciliğinde özel bir yere taşımıştır. Uygur ve Çinli araştırmacıların Hoşur'un sanat anlayışı ve eserleri üzerinde 2017 yılına kadar yaptığı onlarca inceleme ve değerlendirme çalışması bulunmaktadır. Bıyık Macerası'nın gerçek değerini Yalkun Rozi dile getirebilmiştir. Hikâye, konusunun hassas olmasına rağmen Uygurca web sitelerinde çokça paylaşılmıştır. Okuma yazması bulunan her bir Uygur tarafindan okunmuştur desek abartmış olmayız. 2009 sonrası birçok Uygurca web siteleri bu tür eserleri paylaştıkları için kapatılmış, site sahipleri hapse atılmıştı. 2017 yılından beri ise sansür hat safhaya ulaşmış, Doğu Türkistan tamamen ablukaya alınmış durumdadır. Şu an Uygurca web sitelerin açık olanları eğlence ve siyasi propaganda amaçlı kullanılmaktadır.

1: Bu yazı; İstanbul Üniversitesinin BYP-2018-28270 numaralı BAP projesi kapsamında, 29-31 Mart 2018 tarihinde Ankara'da düzenlenen 6. Uluslararası Çin'den Adriatik'e Sosyal Bilimler Kongresi'nde sunulan “Uygur Yazar Memtimin Hoşur'un Bıyık Macerası Adlı Eserinde Sosyal Sorunlar” başlıklı bildirinin genişletilmiş şeklidir. 


\section{Kaynakça}

Aksu, M. (2016). Bıyık macerası. Çağdaş Uygur hikâyelerinden seçmeler (Çeviri.) 225-256, Ankara: Gazi.

Çanışev, S. (2016). Göz yaşlarıyla ıslanan topraklar (İdikut, Çev.) Ankara: Gece.

Çetişli, İ. (2009). Metin tahlillerine giriş-2, Ankara: Akçağ.

Doğan, L. (2021). Muallimin mektubu. Türk dünyasında isyan ve başkaldırt-Edebiyata yansıyan özgür ruh -Çeviri- (O. Söylemez ve S. Azap, Ed.) İstanbul: Kesit, 625-630.

Forster, E. M. (1982). Roman sanatı (Ü. Aytür, Çev.) İstanbul: Adam.

Hasancan, A. (2016). Çağdaş Uygur yazarı Mehmet Emin Hoşur ve eserleri. Uluslararası Uygur araştırmaları dergisi, 8, 1-9.

Hoşur, M. (1991). Burut macirasi. Tarim jornili 1, 20-29.

İnayet A. (2009). Çağdaş Uygur edebiyatında bir hikâye: Çenıkış, Türk dünyası incelemeleri dergisi IX (2), 73-117.

İsmayil A, İslam M. (1993). Hazirki zaman Uygur edipliri. Ürümçi: Şincan helk.

Komisyon (2006a). Uygur edebiyatı tarihi 3. Pekin: Milletler.

Komisyon (2006b). Uygur edebiyatı tarihi 4/1. Pekin: Milletler.

Komisyon (2006c). Uygur edebiyatı tarihi 4/2. Pekin: Milletler.

Polat, M. (1985). Uygur edebiyatıda proza. Ürümçi: Şincan helk.

Rozi, Y. (1991). Bulut macerası"ning kimmiti. Tarim, 12, 144-146

Sartekin, E. A. (2006). Uygurçe neşr kilingan tebbiy edebiy eserler katalog., 2. Ürümçi: Şincan helk sehiye.

Sultan A. (2001). 20-esir Uygur edebiyatinin umumiy ehvali. İlmiy makaliler toplimi. Ürümçi: Şincan üniversitesi. 1-37.

Sultan, A. Abdurehim, K. (2002). Uygur bügünki zaman edebiyat tarihi. Ürümçi: Şincan Üniversitesi.

Süvürof, S. (2010). Men keçken keçikler (3. Basım). Pekin: Milletler.

Tatlik E. (2004). 1949 yildin burun Şincangda Uygur tilida neşir kilinğan gézit-jornallar. Şinciang tezkiriçiliki jornili, 3, 51-58.

Zaman, N. (1984). Hazirki zaman Uygur edebiyatining şekillinişi hekkide bezi karaşlirim. Şincang Üniversitesi ilmiy jornili, 4, 86-96

https://www.youtube.com/watch? $\mathrm{v}=\mathrm{CWkmKnBmf-Y \& t=70s} \mathrm{(E.} \mathrm{T.} \mathrm{01.12.2020)}$ 